\title{
Beinpéttni ungra kvenna með sögu um lystarstol
}

Rebekka Guðrún Rúnarsdóttir læknanemi, Guðlaug Porsteinsdóttir² læknir, Ólafur Skúli Indriðason³ læknir, Gunnar Sigurðsson læknir

\section{ÁGRIP}

Tilgangur: Lág beinbéttni er algeng hjá sjúklingum með lystarstol en pað vantar rannsóknir hérlendis á beinheilsu pessa sjúklingahóps. Tilgangur rannsóknarinnar var að kanna beinpéttni ungra kvenna sem hafa greinst með lystarstol á Íslandi og öðlast betri skilning á mögulegum orsakapáttum lágrar beinpéttni.

Efniviður og aðferðir: Rannsóknin var afturskyggn. Skoðaðar voru sjúkraskrár kvenna sem höfðu leitað sér meðferðar hjá átröskunarteymi Landspítala á árunum 2001-2009, voru greindar með lystarstol eða höfðu sögu um lystarstol (F50.0, F50.1) og farið í beinpéttnimælingu. Konur yngri en 18 ára og eldri en fertugar voru útilokaðar. Niðurstöður voru bornar saman við heilbrigðar 30 ára konur sem tóku pátt í rannsókn á beinheilsu Íslendinga á árunum 2001-2003 ( $n=58)$.

Niðurstöður: Við beinpéttnimælingu var meðallíkamspyngdarstuðull (LPS: kg/m²) lystarstolshóps (n=40) 17,4 (12,3-25,2) miðað við 23,6 (18,1$43,7)$ hjá samanburðarhópi $(p<0,001)$. Beinpéttni i lendhrygg og mjöðm var 15,3-17,5\% lægri hjá lystarstolshópnum ( $p<0,001)$. Hjá báđum hópum var sterk fylgni beinpéttni við pyngd $(r=0,354-0,604, p<0,05)$ og mjúkvefjamagn $(r=0,425-0,588, p<0,05)$, mismikið eftir mælistöðum. Meðal lystarstolssjúklinga var einnig fylgni milli beinpéttni og minnstu pyngdar í veikindum $(r=0,482-0,499, p<0,01)$. Hjá lystarstolssjúklingum sem áttu endurteknar beinpéttnimælingar $(n=26)$ og töpuðu pyngd milli mælinga minnkaði beinpéttnin í lærleggshálsi um 6,6\% $(p=0,030)$. Pær sem voru að jafnaði með LPS $\leq 17,5$ milli mælinga töpuðu $5,5-7,1 \%$ af beinpéttni í mjöðm $(p<0,05)$.

Ályktanir: Í samanburði við heilbrigðar ungar konur er beinpéttni kvenna með lystarstol um $15 \%$ lægri. Beinpéttni virðist tengjast pyngd á svipaðan hátt hjá báđum hópum og líkamspyngd pví sennilega mikilvægasti áhrifavaldur á beinpéttnina og mögulega einnig á hámarksbeinmagn pessara sjúklinga.
Fyrirspurnir:

Gunnar Sigurðsson gunnars@landspitali.is

Greinin barst:

16. mars 2012, sampykkt til birtingar 23. júlí 2012.

Engin hagsmunatengsl gefin upp.

\section{Inngangur}

Lág beinpéttni er algeng hjá sjúklingum með lystarstol (anorexia nervosa), geðsjúkdóm sem einkennist af meðvituðu svelti, pyngdartapi og röskun á hormónastarfsemi líkamans. ${ }^{1,2}$ Lystarstol er einn af undirflokkum átraskana ásamt lotugræðgi (bulimia nervosa) og öðrum ósértækum átröskunum (eating disorders not otherwise specified). Pyngdarmörk í lystarstoli samkvæmt greiningarviðmiðum DSM-IV og ICD-10 eru að einstaklingur sé undir $85 \%$ af peirri pyngd sem ætla mætti að væri eðlileg miðað við aldur hans og hæð. Hjá börnum og unglingum er betra að notast við vaxtarkúrfur, en hjá fullorðnum hefur verið miðað við líkamspyngdarstuðul (LPS: $\left.\mathrm{kg} / \mathrm{m}^{2}\right), \leq 17,5$ sem eru ströng viðmið pegar haft er í huga að Alpjóðaheilbrigðisstofnunin skilgreinir undirpyngd sem LPS $<18,5$.

Átraskanir eru langvinnir sjúkdómar og einkenni geta verið breytileg. Ekki er óalgengt að sjúklingar færist milli átröskunargreininga í sjúkdómsferlinu, par sem greiningarskilmerkin eru ströng, til dæmis að sjúklingur með lystarstol prói síðar með sér lotugræðgi eða ósértæka átröskun og öfugt., ${ }^{3,4}$ Ekki eru til tölur um batahorfur á Íslandi, fyrir utan dánartíðni einstaklinga sem hafa verið lagðir inná geðdeild vegna lystarstols, ${ }^{5}$ en pýsk rannsókn sem fylgdi eftir sjúklingum með lystarstol eftir innlögn á sjúkrahús lýsti pví að 12 árum síðar voru 30\% enn með lystarstol og 9,5\% höfðu fengið lotugræðgi. Staðlað dánarhlutfall í pýsku rannsókninni var 8,8 en 6,25 í peirri íslensku. ${ }^{5,6}$

Einn alvarlegasti líkamlegi fylgikvilli lystarstols er röskun á beinpéttni. Nærtæk skýring er að lystarstol byrjar venjulega snemma á unglingsárum pegar mesta aukning á beinmagni á sér stað og veikindin geta varað í mörg ár. ${ }^{7}$ Yfir $95 \%$ af hámarksbeinmagni einstaklings er náð fyrir 18 ára aldur en hámarksbeinmagni er að fullu náo um 18,5 ára aldur í mjöðm en við 23 ára aldur í lendhrygg. ${ }^{8,9}$ Hjá lystarstolssjúklingum getur beinaukningin pví orðið minni og leitt til lægra hámarksbeinmagns eftir að beinvexti er lokið, en pað getur ráðið miklu um á hvaða aldri einstaklingur er kominn með beinpynningu vegna aldursbundins beintaps síðar á ævinni. Hámarksbeinpéttni er pví mikilvægur páttur í framtíðarbeinheilsu og hættu á beinbrotum.

Skilgreining Alpjóðaheilbrigðisstofnunarinnar á beinpynningu byggist á mælingum á beinpéttni með dual-energy X-ray absorptiometry (DXA). Beinpynning er skilgreind sem beinpéttni meira en 2,5 staðalfrávikum neðan meðaltals ungra einstaklinga (20-29 ára) með hámarksbeinmagn, og beinrýrnun sem beinpéttni sem er 1,0-2,5 staðalfrávikum neðan pessa meðaltals..$^{10}$ Fyrir hvert staðalfrávik sem beinpéttni lækkar, eykst hætta á beinbroti um pað bil tvöfalt. ${ }^{11}$ Beinpéttni er mæld í lendhrygg og mjöðm sem innihalda hátt hlutfall frauðbeins. Í heild er beinagrind fullorðinna $80 \%$ skelbein en í lendhrygg er um 70\% frauðbein og um 50\% í lærleggshálsi. Frauðbein hefur mikið yfirborð sem leyfir hraðara beinumbrot og pví kemur beinpynning frekar fram par. ${ }^{12}$

Rannsóknir hafa sýnt að hjá ungum konum með lystarstol eru um 20-38\% með beinpynningu og um 47-54\% með beinrýrnun samkvæmt ofannefndri skilgreiningu. ${ }^{1,2,13,14}$ Ungar konur með virkan lystarstols- 
sjúkdóm tapa beinpéttni hratt, eða að meðaltali um 2,5\% á ári. ${ }^{15}$ Undirliggjandi orsök minnkaðrar beinpéttni hjá sjúklingum með lystarstol er flókin og ekki að fullu pekkt, en stafar líklega meðal annars af minni líkamspyngd, skorti á mikilvægum næringarefnum, vanseytingu kynhormóna, vaxtarhormónsviðnámi með lágum insúlín-líkum vaxtarpætti 1 (IGF-1), hækkun á kortisóli og breytingum á hormónum sem hafa með efnaskipti beina að gera, svo sem leptíni, peptíði YY, adiponectíni, insúlíni og amylíni. ${ }^{16}$

Með bata, pyngdaraukningu og endurkomu tíðablæðinga virðist beintapið ganga til baka að hluta til.1718 Sýnt hefur verið fram á að pyngdaraukning sé mikilvæg fyrir endurbata á beinpéttni î mjöðm, en endurkoma tíðablæðinga sé mikilvæg fyrir endurbata á beinpéttni í hrygg. ${ }^{15}$ I klínískum leiðbeiningum amerísku geðlæknasamtakanna er ráðlagt að allir sjúklingar sem greinst hafa með lystarstol og hafa sögu um blæðingastopp í 6 mánuði fari í beinpéttnimælingu. ${ }^{19}$

Tilgangur rannsóknarinnar var að kanna beinpéttni ungra kvenna með sögu um lystarstol á Íslandi og öðlast betri skilning á mögulegum orsökum lítillar beinpéttni.

\section{Efniviður og aðferðir}

Rannsóknin var afturskyggn. Rannsóknarpýðið var fundið með pví að skoða sjúkraskrár kvenna sem höfðu leitað sér meðferðar hjá átröskunarteymi Landspítala á árunum 2001 til 2009 og farið í beinpéttnimælingu á spítalanum. Petta tímabil var valið af pví að árið 2001 var fyrst sett á stofn teymi um meðferð fullorðinna einstaklinga með átraskanir á geðsviði spítalans. Fóru pá allnokkrir í beinpéttnimælingar. Árin 2004 og 2005 var hlé á starfseminni, en í febrúar 2006 hófst hún á ný og hafa einstaklingar með lystarstol eða sögu um lystarstol markvisst verið sendir í beinpéttnimælingar eftir pað. Að jafnaði hafa um 10 nýir sjúklingar á ári greinst með lystarstol hjá teyminu og farið í beinpéttnimælingu. Einnig hafa einstaklingar sem hafa sögu um lystarstol verið beinpéttnimældir pó sjúkdómurinn hafi próast yfir í lotugræðgi eða aðrar átraskanir pegar leitað var meðferðar. Pátttökuskilyrði í rannsókninni voru að hafa fengið ICD-10 greiningarnar lystarstol (F50.0) eða ódæmigert lystarstol (F50.1) ${ }^{20}$ og hafa farið í beinpéttnimælingu í veikindum sínum. Við útilokuðum pær sem voru yngri en 18 ára og eldri en 40 ára við beinpéttnimælinguna. Samanburðarhópur var fenginn úr rannsókn á beinheilsu Íslendinga sem framkvæmd var á árunum 2001-2003 með sama beinpéttnimælitæki. Par var um að ræða 58 heilbrigðar 30 ára konur, slembiúrtak af Reykja-

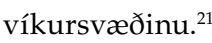

Við beinpéttnimælinguna svöruðu konurnar stöðluðum spurningalista. Par var spurt um tíðablæðingar, lyf, reykingar, fjölskyldusögu um beinpynningu, sjúkdóma, neyslu mjólkurafurða, töku kalks, lýsis og vítamíns, líkamsrækt og beinbrot. Konurnar voru einnig vigtaðar og hæðarmældar.

Upplýsingum var safnað um niðurstöður beinpéttnimælinga og úr spurningalistum ásamt upplýsingum úr sjúkraskrám Landspítala fyrir lystarstolshópinn.

Rannsóknin var prípætt, í fyrsta lagi samanburður sjúklinga með lystarstol við heilbrigða einstaklinga, í öðru lagi tengsl beinpéttni meðal lystarstolssjúklinga við mögulega áhrifapætti og 1 priðja lagi voru skoðaðir sérstaklega peir lystarstolssjúklingar sem
Tafla I. Grunnupplýsingar fyrir átröskunarsjúklinga með lystarstol eða sögu um lystarstol og samanburðarhóp við beinpéttnimælingu.

\begin{tabular}{|c|c|c|c|}
\hline & $\begin{array}{l}\text { Lystarstolshópur } \\
\qquad(\mathrm{n}=40)\end{array}$ & $\begin{array}{l}\text { Samanburðarhópur } \\
\qquad(\mathrm{n}=58)\end{array}$ & p-gildi \\
\hline Aldur (ár) & $21,5(18,2-36,5)$ & $30(29-30)$ & $<0,001$ \\
\hline Pyngd (kg) & $47(36-69)$ & $69(47-111)$ & $<0,001$ \\
\hline Нæð (cm) & $166 \pm 7$ & $167 \pm 6$ & 0,521 \\
\hline $\operatorname{LPS}\left(\mathrm{kg} / \mathrm{m}^{2}\right)$ & $17,4(12,3-25,2)$ & $23,6(18,1-43,7)$ & $<0,001$ \\
\hline Lýsi og/eða vítamín (\%) & $66^{\mathrm{a}}$ & 40 & 0,012 \\
\hline Kalktöflur (\%) & $49^{b}$ & 10 & $<0,001$ \\
\hline Líkamsrækt ( $\geq 3 x$ í viku) (\%) & $33^{c}$ & 40 & 0,538 \\
\hline Reykir eða hefur reykt (\%) & $59^{d}$ & 40 & 0,062 \\
\hline Saga um beinbrot (\%) & $40^{\mathrm{a}}$ & 22 & 0,072 \\
\hline Reglulegar blæðingar (\%) & 23 & 85 & $<0,001$ \\
\hline $\begin{array}{l}\text { Aldur við upphaf } \\
\text { blæðinga (ár) }\end{array}$ & $13(10-18)^{e}$ & $13(11-17)$ & 0,460 \\
\hline Tekur p-pilluna (\%) & 23 & - & - \\
\hline
\end{tabular}

Gögn eru sett fram sem meðaltal \pm staðalfrávik fyrir normaldreifðar breytur en miðgildi (spönn) fyrir breytur sem ekki eru normaldreifðar. LPS: Líkamspyngdarstuðull. ${ }^{a} \mathrm{n}=38$, ${ }^{b} n=37,{ }^{c} n=36,{ }^{d}=39,{ }^{e} n=27$.

höfðu farið í beinpéttnimælingu oftar en einu sinni til að meta breytingar í beinpéttni og pætti sem tengdust slíkum breytingum.

Tilskilin leyfi fyrir rannsókninni fengust hjá siðanefnd Landspítala, Persónuvernd og framkvæmdastjóra lækninga á Landspítala.

\section{Mat á beinpéttni}

Beinpéttni var mæld með DXA, Hologic QDR 4500A (Hologic, Bedford MA, Bandaríkjunum) í báðum hópum. Pessi aðferð mælir magn steinefna, aðallega kalks, á flatareiningu $\left(\mathrm{g} / \mathrm{cm}^{2}\right)$, pað er beinpéttni í tvívídd. Beinpéttnimælingar eru almennt gerðar á lendhrygg og vinstri mjöðm. Í lendhrygg er mæld beinpéttni í L1-L4 og í mjöðm er annars vegar mæld beinpéttni í lærleggshálsi og hins vegar í öllum nærenda lærleggs sem samanstendur af lærleggshálsi, lærhnútum og beini milli lærhnúta. Ómarkvísi mælinga í lendhrygg er 1,0\% en ómarkvísi mælinga í mjöðm er $1,6 \%{ }^{22}$ DXA-tækið getur einnig mælt heildarbeinpéttni fyrir alla beinagrindina, metið líkamspyngd og magn fitu og mjúkvefs. Mjúkvefur er vefur sem er hvorki fituvefur né beinvefur, en er að stærstum hluta vatn og vöðvar og er magn hans talið endurspegla vöðvamagn líkamans.

\section{Tölfræðileg greining}

Gögn eru sett fram sem hlutfall (\%) fyrir flokkunarbreytur og sem miðgildi (spönn) fyrir samfelldar breytur sem ekki eru normaldreifðar, en meðaltal \pm staðalfrávik fyrir normaldreifðar breytur. Hópar voru bornir saman með t-prófi eða Wilcoxon-Mann-Whitney prófi, kí-kvaðrat prófi og dreifigreiningu (Analysis of covarince, ANCOVA) pegar leiðrétt var fyrir breytum. Fylgni var könnuð með fylgnistuðli Pearsons eða Spearmans. Hjá sjúklingum með endurteknar beinpéttnimælingar voru breytingar kannaðar með pöruðu t-prófi eða Wilcoxon signed ranks prófi. Við tölfræðiúrvinnslu var 
Tafla II. Beinpéttni $\left(\mathrm{g} / \mathrm{cm}^{2}\right)$, magn fitu (kg) og mjúkvefjar hjá lystarstolshópi og samanburðarhópi.

\begin{tabular}{lcccc} 
& & $\begin{array}{c}\text { Lystarstolshópur } \\
(\mathrm{n}=40)\end{array}$ & $\begin{array}{c}\text { Samanburðarhópur } \\
(\mathrm{n}=58)\end{array}$ & $\begin{array}{c}\text { Munur } \\
(\%)\end{array}$ \\
\hline Beinpéttni lendhryggur & $0,903 \pm 0,125$ & $1,066 \pm 0,124$ & $15,3^{*}$ \\
& T-gildi & $-1,3 \pm 1,2$ & $0,0 \pm 1,0$ & \\
\hline Beinpéttni lærleggsháls & $0,721 \pm 0,091$ & $0,874 \pm 0,113$ & $17,5^{*}$ \\
& T-gildi & $-1,1 \pm 0,8$ & $0,0 \pm 1,0$ & \\
\hline Beinpéttni nærendi lærleggs & $0,805 \pm 0,101$ & $0,967 \pm 0,111$ & $16,8^{*}$ \\
\hline Heildarbeinpéttni beinagrindar & $1,065 \pm 0,084^{\mathrm{a}}$ & $1,135 \pm 0,082$ & $6,2^{*}$ \\
\hline Magn fitu & $-1,1 \pm 0,8$ & $0,0 \pm 1,0$ & \\
\hline Magn mjúkvefjar & $11,22 \pm 4,91^{\mathrm{a}}$ & $23,61 \pm 10,06$ & $52,5^{*}$ \\
\hline
\end{tabular}

Gögn eru sett fram sem međaltal \pm staðalfrávik. ${ }^{*} p<0,001,{ }^{a} n=33$.

notast við SPSS 17.0 (IBM, Armonk, New York, Bandaríkjunum) og miðað var við tölfræðilega marktækni við $\mathrm{p}<0,05$.

\section{Niðurstöður}

Alls fundust 63 einstaklingar sem höfðu leitað sér meðferðar hjá átröskunarteymi Landspítala og farið í beinpéttnimælingu, en 40 einstaklingar uppfylltu pátttökuskilyrði rannsóknarinnar. Ástæður pess að einstaklingar voru útilokaðir voru að 8 höfðu fengið greiningu á annarri átröskun en lystarstoli, 8 voru eldri en 40 ára við beinpéttnimælinguna, prír voru yngri en 18 ára og fjórir voru útilokaðar af öðrum ástæðum (vegna beinaukandi lyfja, fíkniefnanotkunar, lystarstolsgreining talin óréttmæt og að gögn fundust ekki). Beinpéttnimælingarnar voru framkvæmdar á árunum 2001 til 2010. Ríflega helmingur rannsóknarhóps $(n=23)$ var með LPS $\leq 17,5$ við beinpéttnimælingu og uppfyllti pví pyngdarviðmið fyrir lystarstol samkvæmt greiningarskilmerkjum ICD-10. Sex einstaklingar höfðu LPS 17,6-18,4 og 11 voru í kjörpyngd með LPS 18,625,2 .

Við söfnun gagna fengust ekki alltaf allar breytur. Í einu tilviki fannst ekki spurningalisti, stundum höfðu ekki fengist svör við öllum spurningunum og upplýsingar um breytur tengdar lystarstoli fundust ekki alltaf í sjúkraskrám. Hjá lystarstolshópnum hafði ekki alltaf verið gerð mæling fyrir allan líkamann með mælingu á heildarbeinpéttni, auk fitu- og mjúkvefjamagns $(n=33)$.

Samanburður lystarstolshóps og viðmiðunarhóps

Konurnar í lystarstolshópnum voru yngri en samanburðarhópurinn og tóku frekar lýsi og/eða vítamín og kalktöflur, og aðeins 23\% peirra voru með reglulegar blæðingar pegar beinpéttnimælingin var gerð (tafla I). Önnur 23\% lystarstolssjúklinga tóku p-pilluna og óvíst hversu stór hluti peirra var með reglulegar blæðingar en priðjungur peirra var með LPS yfir 17,5. Hlutfallslega fleiri í lystarstolshópnum höfðu beinbrotnað en munurinn var ekki marktækur. Pær voru marktækt léttari en samanburðarhópurinn en jafnháar (tafla I). Miðgildi aldurs við upphaf veikinda var 16 ár (spönn 10-31 ár) og hafði átröskunin staðið í 5 (1-19) ár. Minnsta skráða pyngd í veikindum var 41 (27-58) kg og mesta pyngd 56 $(45-100) \mathrm{kg}$.

Lystarstolshópurinn var með marktækt lægri beinpéttni en samanburðarhópur (tafla II). Í lendhrygg og mjöðm var 15,317,5\% munur á beinpéttni milli hópanna og 6,2\% munur á heildarbeinpéttni beinagrindar $(\mathrm{p}<0,001)$. Pegar leiðrétt var fyrir pyngd minnkaði munurinn á beinpéttni milli hópanna. Eftir leiðréttinguna var munurinn á beinpéttni í lærleggshálsi 9,0\% ( $p=0,004)$, nærenda lærleggs 9,9\% ( $p=0,001)$ og ekki var lengur marktækur munur á beinpéttni í lendhrygg og heildarbeinpéttni.

Meðal kvenna með lystarstol var hátt hlutfall með beinrýrnun eða beinpynningu í lendhrygg, lærleggshálsi og/eða nærenda lærleggs. Aðeins 30\% kvennanna í lystarstolshópnum höfðu eðlilega beinpéttni á öllum premur beinsvæðunum samkvæmt skilgreiningu Alpjóðaheilbrigðisstofnunarinnar, 55\% höfðu beinrýrnun eða beinpéttni 1,0-2,5 staðalfrávikum (T-gildi) neðan meðaltals ungra kvenna, og 15\% höfðu beinpynningu eða beinpéttni meira en 2,5 staðalfrávikum neðan meðaltals ungra kvenna. Í samanburðarhópnum voru 74,1\% kvenna með eðlilega beinpéttni og engin hafði beinpynningu (mynd 1).

Fylgni pyngdar við beinpéttni fannst hjá báðum hópum og virtist samfelld yfir pyngdarskalann (mynd 2). Fylgni mjúkvefjamagns við beinpéttni sýndi svipaðar niðurstöður, en ekki var fylgni milli fitumagns og beinpéttni.
Mynd 1. Hlutfall beinpynningar (T-gildi $\leq-2,5$ ), beinrýrnunar ( $T$ gildi $<-1,0$ og $>-2,5)$ og eðlilegrar beinpéttni hjá lystarstolshópi og samanburðarhópi.
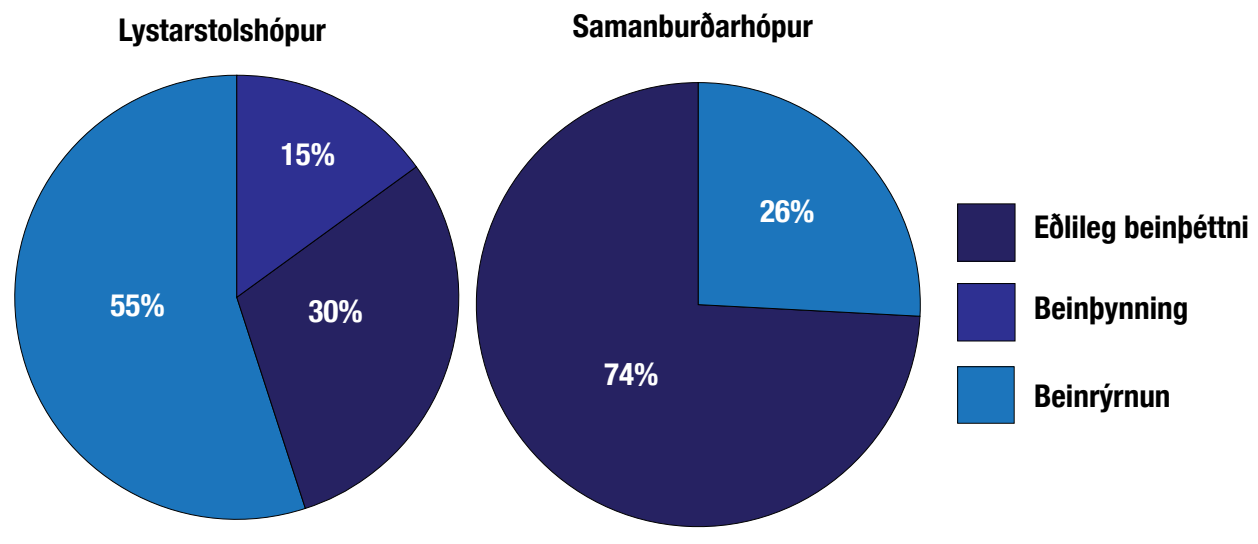
Mynd 2. Beinpéttni $i$ lendhrygg annars vegar og i lærleggshálsi hins vegar sem fall af pyngd.
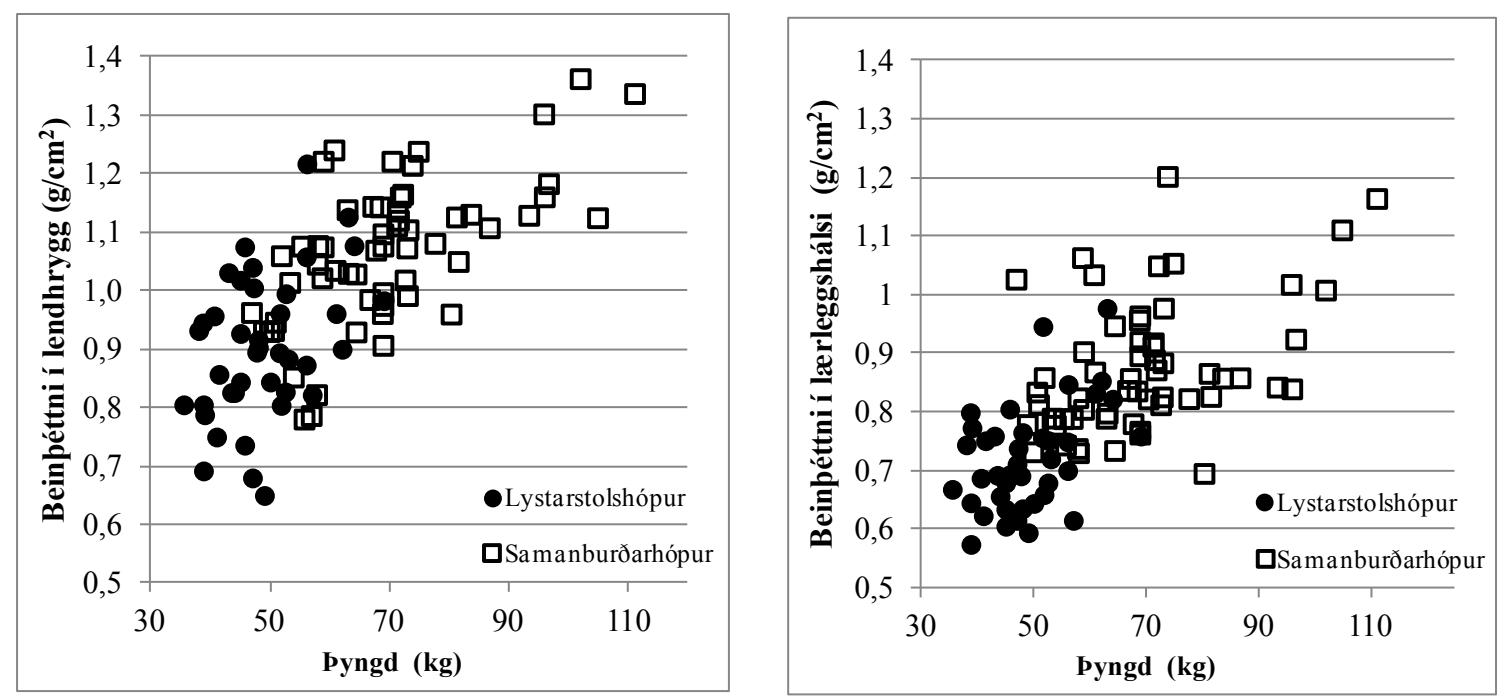

Tengsl beinpéttni og annarra pátta meðal lystarstolssjúklinga

Meðal kvenna með lystarstol var mest fylgni beinpéttni við lægstu pyngd í veikindum $(\mathrm{r}=0,482-0,499, \mathrm{p}<0,01)$ og magn mjúkvefjar $(\mathrm{kg})(\mathrm{r}=0,443-0,560, \mathrm{p}<0,01)$ (tafla III). Ekki kom fram marktæk fylgni beinpéttni við aldur við beinpéttnimælingu, aldur við upphaf átröskunar, lengd átröskunar, aldur við upphaf blæðinga né tímalengd blæðinga meðal lystarstolshóps. Pær konur sem stunduðu líkamsrækt prisvar eða oftar í viku voru með marktækt hærri heildarbeinpéttni $(6,5 \%, p=0,040)$ en hinar sem æfðu minna, en ekki var munur á beinpéttni í lendhrygg eða mjöðm. Ekki var marktækur munur á beinpéttni eftir pví hvort konurnar í lystarstolshópnum tóku lýsi og/eða vítamín, tóku kalktöflur, reyktu/ höfðu reykt, tóku p-pilluna eða voru með reglulegar blæðingar.

Skoðuð voru nokkur blóðgildi kvenna með lystarstol með tilliti til hugsanlegra tengsla við beinpéttni, meðal annars kalíum og kortisól. Til voru mælingar fyrir kalíum hjá 38 konum og kortisóli hjá 33 konum en pær mælingar voru fæstar gerðar í tengslum við beinpéttnimælinguna. Ekki var fylgni milli beinpéttni og pessara blóðgilda. Pegar skoðuð var beinpéttni kvennanna eftir pví hvort fyrir lægju blóðgildi utan viðmiðunarmarka eða ekki, kom í ljós að hjá peim konum sem höfðu mælst með kalíum undir viðmiðunarmörkum 3,5 mmól/L ( $\mathrm{n}=12)$ var beinpéttnin marktækt lægri en hjá hinum sem höfðu ekki sögu um kalíumskort (n=26). Pær sem höfðu sögu um kalíumskort höfðu lægri beinpéttni í lendhrygg (8,9\%, p=0,048), lærleggshálsi $(8,9 \%, \mathrm{p}=0,021)$, nærenda lærleggs $(10,5 \%, p=0,008)$ og heildarbeinpéttni $(6,4 \%, p=0,032)$.

\section{Endurteknar beinpéttnimælingar}

Í lystarstolshópnum lágu fyrir fleiri en ein beinpéttnimæling hjá 26 konum með 2,6 (1,2-5,7) ára millibili. Fyrir allan hópinn varð að meðaltali ekki marktæk breyting á beinpéttni milli mælinga en magn fitu jókst um 33,9\% (p=0,038). Hugsanlegir áhrifapættir voru skoðaðir í sambandi við breytingar á beinpéttni og ekki fannst munur eftir pví hvort konurnar tóku lýsi og/eða vítamín, tóku kalktöflur né hvort pær reyktu/höfðu reykt.

Er lystarstolshópnum var skipt eftir pví hvort konurnar pyngdust eða léttust milli beinpéttnimælinga kom í ljós að pær sem pyngdust bættu á sig 2 (1-31) kg (n=17). Ekki varð breyting á beinpéttni peirra, en magn fitu jókst um $54,6 \%(p=0,003)$ og magn mjúkvefja um 6,6\% (p=0,023). Pær sem léttust töpuðu 4 (1-7) kg milli beinpéttnimælinga og lækkuðu í beinpéttni í lærleggshálsi um $6,6 \%(\mathrm{p}=0,030)$ ásamt pví að tapa mjúkvef $(6,5 \%, \mathrm{p}=0,028)$ $(\mathrm{n}=9)$.

Hjá peim konum sem voru að mestu með LPS yfir 17,5 milli beinpéttnimælinga, óháð pyngdarbreytingu, breyttist beinpéttnin ekki marktækt. Pær konur sem voru með LPS undir 17,5 milli

Tafla III. Fylgni beinpéttni við hæð og pyngd hjá lystarstolshópi og samanburðarhópi.

\begin{tabular}{|c|c|c|c|c|c|c|c|c|}
\hline & \multicolumn{4}{|c|}{ Lystarstolshópur (n=40) } & \multicolumn{4}{|c|}{ Samanburðarhópur ( $n=58)$} \\
\hline & $\begin{array}{l}\text { Beinpéttni } \\
\text { lendhryggur }\end{array}$ & $\begin{array}{l}\text { Beinpéttni } \\
\text { lærleggsháls }\end{array}$ & $\begin{array}{l}\text { Beinpéttni } \\
\text { nærenda } \\
\text { lærleggs }\end{array}$ & $\begin{array}{l}\text { Heildar- } \\
\text { beinpéttnia }\end{array}$ & $\begin{array}{l}\text { Beinpéttni } \\
\text { lendhryggur }\end{array}$ & $\begin{array}{c}\text { Beinpéttni } \\
\text { lærleggsháls }\end{array}$ & $\begin{array}{c}\text { Beinpéttni } \\
\text { nærenda } \\
\text { lærleggs }\end{array}$ & $\begin{array}{l}\text { Heildar- } \\
\text { beinpéttni }\end{array}$ \\
\hline Pyngd við mælingu & $0,410^{\star \star}$ & $0,455^{\star \star}$ & $0,368^{*}$ & 0,319 & $0,604^{\star \star}$ & $0,440^{\star \star}$ & $0,354^{\star *}$ & $0,390^{\star \star}$ \\
\hline Hæð við mælingu & $0,336^{*}$ & $0,434^{\star *}$ & $0,424^{\star *}$ & $0,350^{*}$ & 0,048 & 0,085 & 0,177 & 0,177 \\
\hline LPS við mælingu & 0,274 & 0,260 & 0,164 & 0,189 & $0,573^{\star \star}$ & $0,342^{\star \star}$ & 0,255 & $0,273^{*}$ \\
\hline Minnsta pyngd & $0,499^{\star *}$ & $0,482^{\star *}$ & $0,490^{\star *}$ & $0,497^{\star *}$ & - & - & - & - \\
\hline Mesta pyngd & $0,308^{b}$ & $0,290^{b}$ & $0,133^{b}$ & 0,338 & - & - & - & - \\
\hline Pyngd fitu & 0,259 & 0,190 & 0,211 & 0,067 & 0,178 & 0,071 & 0,070 & $-0,088$ \\
\hline Pyngd mjúkvefjar & $0,463^{\star \star}$ & $0,560^{\star \star}$ & $0,433^{*}$ & 0,443 & $0,588^{\star \star}$ & $0,425^{\star \star}$ & $0,455^{\star \star}$ & $0,493^{\star \star}$ \\
\hline
\end{tabular}

Fylgnistuðull (r). ${ }^{*} \mathrm{p}<0,05,{ }^{* *} \mathrm{p}<0,01,{ }^{a} \mathrm{n}=33,{ }^{\mathrm{b}} \mathrm{n}=39$.

LPS - Líkamspyngdarstuðull. 
Tafla IV. Breytingar í beinpéttni $\left(\mathrm{g} / \mathrm{cm}^{2}\right)$, samanburður milli peirra sem voru með líkamspyngdarstuðul að mestu undir $17,5 \mathrm{~kg} / \mathrm{m}^{2} \mathrm{milli}$ mælinga og peirra sem voru pað ekki.

\begin{tabular}{|c|c|c|c|c|}
\hline & $\begin{array}{l}\text { LPS }>17,5 \mathrm{~kg} / \mathrm{m}^{2} \\
\text { milli mælinga }(n=9)\end{array}$ & Breyting (\%) & $\begin{array}{l}\mathrm{LPS} \leq 17,5 \mathrm{~kg} / \mathrm{m}^{2} \\
\text { milli mælinga }(\mathrm{n}=17)\end{array}$ & Breyting (\%) \\
\hline Beinpéttni lendhryggur & $0,059 \pm 0,109$ & $7,6 \pm 15,3$ & $-0,011 \pm 0,058$ & $-1,0 \pm 6,8$ \\
\hline Beinpéttni lærleggsháls & $0,024 \pm 0,075$ & $3,7 \pm 11,6$ & $-0,053 \pm 0,060$ & $-7,1 \pm 7,9^{\star \star}$ \\
\hline Beinpéttni nærendi lærleggs & $0,033 \pm 0,090$ & $4,3 \pm 11,7$ & $-0,043 \pm 0,061$ & $-5,5 \pm 8,0^{*}$ \\
\hline Heildarbeinpéttni beinagrindar & $0,028 \pm 0,040^{\mathrm{a}}$ & $2,7 \pm 4,1$ & $-0,012 \pm 0,068^{b}$ & $-0,9 \pm 6,6$ \\
\hline Pyngd (pyngdarbreyting kg) & $6 \pm 12$ & $14,8 \pm 29,3$ & $1 \pm 3$ & $2,2 \pm 7,2$ \\
\hline
\end{tabular}

Gögn eru sett fram sem međaltal \pm staðalfrávik. ${ }^{*} \mathrm{p}<0,05,{ }^{* *} \mathrm{p}<0,01,{ }^{\mathrm{a}} \mathrm{n}=6,{ }^{\mathrm{b}} \mathrm{n}=12$.

beinpéttnimælinga lækkuðu í beinpéttni í lærleggshálsi um 7,1\% ( $p=0,004)$ og í nærenda lærleggs um 5,5\% ( $p=0,015)$ (tafla IV).

\section{Umræða}

Rannsóknin skoðaði beinpéttni hjá ungum konum sem hafa greinst með lystarstol á Íslandi. Niðurstöður sýndu að beinpéttni í lendhrygg og mjöðm hjá lystarstolshópnum var 15,3-17,5\% lægri en í heilbrigðum ungum konum sem náð hafa hámarksbeinpéttni. Hjá báðum hópum var sterk fylgni beinpéttni við pyngd og mjúkvefjamagn. Meðal lystarstolssjúklinga var einnig sterk fylgni beinpéttni við lægstu pyngd í veikindum. Beinpéttni lystarstolssjúklinga sem höfðu endurtekið farið í beinpéttnimælingu breyttist að jafnaði ekki marktækt milli mælinga en pær sem léttust milli mælinga lækkuðu í beinpéttni í lærleggshálsi. pær konur sem voru með LPS >17,5 milli beinpéttnimælinga töpuðu einnig beinpéttni í nærenda lærleggs.

Líkt og erlendar rannsóknir, staðfesti pessi rannsókn tengsl lágrar beinpéttni við lystarstol.,13-15,18,23 Beinpéttni í lendhrygg var 15,3\% lægri eða 1,3 staðalfrávikum neðar en samanburðarhópur og í lærleggshálsi 17,5\% lægri eða 1,1 staðalfráviki neðar. Svipaðar niðurstöður sýndi spænsk rannsókn, par var beinpéttni 1,2-1,4 staðalfrávikum neðar í lendhrygg og mjöðm heldur en hjá samanburðarhópi. ${ }^{13}$ Í pessari rannsókn höfðu 55\% lystarstolssjúklinga beinrýrnun og 15\% beinpynningu á að minnsta kosti einu mældu beinsvæði, en aðeins 30\% höfðu eðlilega beinpéttni. Sambærilegar erlendar rannsóknir hafa sýnt að um helmingur lystarstolssjúklinga hafi beinrýrnun og um priðjungur hafi beinpynningu. ${ }^{1,213,14,23}$ Pessi munur á tíðni beinpynningar skýrist væntanlega af valskekkju, pví alvarleiki sjúkdómsins getur verið misjafn milli rannsóknarhópa. Í rannsókninni voru ekki nema 57,5\% með LPS $\leq 17,5$ pegar beinpéttnimælingin var gerð, sem er eitt greiningarskilmerkja lystarstols.

Fylgni beinpéttni við pyngd var svipuð meðal lystarstolshóps og samanburðarhóps. Athyglisvert er að sjá að pessi fylgni virðist vera nokkuð samfelldur ferill og sams konar samband milli pyngdar og beinpéttni hjá bæði lystarstolshópi og samanburðarhópi. Út frá pví má álykta að hámarksbeinmagn sem einstaklingur almennt nái sé í hlutfalli við pyngd, pað sé kostur að vera pyngri pegar hámarksbeinmagni er náð. Jafnvel ennpá sterkari fylgni var milli beinpéttni og mjúkvefjamagns. Samræmist pað öðrum rannsóknum ${ }^{9,15,24}$ og virðist mjúkvefur pví vera mikilvægasti hluti pyngdaraukningar fyrir bata beinanna á pessum aldri. Ef til vill gæti inngrip sem miðaði að pví að auka vöðvamassa sem hluta af meðferð til pyngdaraukningar verið árangursríkt til að auka beinpéttni lystarstolssjúklinga. Pví til stuðnings má benda á að heildarbeinpéttni var hærri meðal peirra sem stunduðu líkamsrækt prisvar sinnum eða oftar í viku heldur en hinna. Svörun beina við líkamlegri áreynslu hjá lystarstolssjúklingum hefur pó lítið verið rannsökuð, sérstaklega hvort jákvæð áhrif komi fram hjá pessum hópi. Nýleg rannsókn gefur til kynna að pað skipti ekki aðeins máli hvers konar líkamsrækt sé stunduð, heldur einnig á hvaða stigi sjúkdómsins hún sé iðkuð. Ofhreyfing, eins og sífelld ganga á veikindatímabili, getur hugsanlega sett sjúkling í meiri hættu á lágri beinpéttni í hrygg og heildarbeinpéttni, en kraftæfingar með mikilli pyngd geta stuðlað að hækkaðri beinpéttni í lærleggshálsi og heildarbeinpéttni í afturbata sjúkdóms. ${ }^{25}$ Auk fylgni við mjúkvefjamagn var fylgni beinpéttni mest við minnstu pyngd í veikindum meðal lystarstolshóps og pví er mikilvægt að koma í veg fyrir mikið byngdartap í veikindunum.

Beinpéttni lystarstolssjúklinga sem höfðu oft farið í beinpéttnimælingu breyttist að jafnaði ekki marktækt milli mælinga. Hjá peim sem léttust lækkaði beinpéttnin í lærleggshálsi en ekki varð marktæk breyting á beinpéttni hjá peim sem pyngdust. Rannsóknir hafa pó sýnt að með pyngdaraukningu hækki beinpéttnin að hluta til. Til dæmis hefur verið sýnt að beinpéttni hækkaði um 1,6\% í lærleggshálsi, 4,4\% í nærenda lærleggs og 1,3\% í lendhrygg hjá konum sem pyngdust um 10\% eða meira. ${ }^{13}$ Í annarri rannsókn var sýnt að með pyngdaraukningu og endurkomu tíðablæðinga jókst beinpéttnin um 3\% í lendhrygg og 2\% í mjöðm á ári en árlegt beintap var 2,5\% hjá konum með virkan sjúkdóm. ${ }^{15}$ Gera má ráð fyrir að í pað minnsta pær konur í rannsókn okkar sem voru með LPS >17,5 milli mælinga hafi verið með virkan sjúkdóm. Hjá peim lækkaði beinpéttnin árlega um 2,7\% í lærleggshálsi og um 2,1\% í nærenda lærleggs á peim 2,6 árum sem liðu að meðaltali milli beinpéttnimælinga, prátt fyrir litla sem enga pyngdarbreytingu. Erfitt er að meta breytingar út frá tveimur mælingum, pví pað hlýtur að skipta máli hvað gerðist í millitíðinni. Lystarstol getur verið mjög sveiflukenndur sjúkdómur par sem skiptast á sveltitímabil með undirpyngd og tímabil par sem átröskunin tekur á sig aðra mynd og einstaklingar missa sig í átköst eða ofát og pyngjast. Pær konur sem voru með LPS að mestu yfir 17,5 milli mælinga hækkuðu hins vegar ómarktækt í beinpéttni á öllum mældum beinsvæðum, en líklega hefur tími milli mælinga í hluta tilfella verið of stuttur til að bati kæmi fram. Petta bendir pó til pess að mikilvægt sé að halda LPS yfir 17,5 til að viðhalda beinpéttni. Nákvæmara viðmið 
um pað við hvaða ástand líkaminn fer að bæta beinpéttnina fannst í rannsókn sem sýndi fram á að beinpéttni hækkaði ekki nema LPS væri yfir $16,4 \pm 0,3 .{ }^{18}$

Ekki var munur á líkamshæð milli lystarstolshóps og samanburðarhóps sem bendir til pess að konurnar með lystarstol hafi náð fullri hæð, enda yfir 18 ára aldri. Beinbrotatíðni var tæplega tvisvar sinnum hærri meðal lystarstolssjúklinga, pó munurinn væri ekki tölfræðilega marktækur. Í lystarstolshópnum var ekki fylgni milli beinpéttni og aldurs við beinpéttnimælingu, aldurs við upphaf átröskunar, lengd átröskunar, aldurs við upphaf blæðinga né tímalengd blæðinga. Nokkuð kom á óvart að ekki skyldi vera fylgni milli beinpéttni og lengdar átröskunar en margar erlendar rannsóknir hafa sýnt fram á slíka fylgni ${ }^{18,26,27}$ en pó ekki allar. ${ }^{13,14}$ Hugsanleg skýring er að sjúklingar með lystarstol geta verið í talsverðum pyngdarsveiflum á veikindatímanum. Áhugavert var að peir sjúklingar sem höfðu liðið kalíumskort höfðu lægri beinpéttni en hinar. Kalíumskortur bendir líklega til viðvarandi og mikillar losunarhegðunar hjá sjúklingum til að stýra pyngd sinni. Sjúklingarnir stunda pá uppköst eða misnota hægðalyf eða pvagræsilyf. Uppköst og misnotkun pvagræsilyfja geta valdið blóðlýtingu og misnotkun hægðalosandi lyfja getur valdið blóðsýringu. Vegna takmarka gagnanna var ekki hægt að útskýra tengslin nánar, en mælingar á elektrólýtum eru hluti af venjubundinni skoðun hjá sjúklingum sem leita meðferðar vegna átröskunar. Pessar niðurstöður um tengsl kalíumskorts og beinpéttni eru aðeins tilgáta en parf að skoða nánar.

Helstu annmarkar pessarar rannsóknar voru að rannsóknarhópurinn var ekki einsleitur við beinpéttnimælingu og aldursspönn, lengd veikinda ólík og pyngdarspönn allvío. Pannig var rúmur fjórðungur rannsóknarpýðis innan kjörpyngdarmarka við mælinguna. Allir áttu pó sameiginlegt að vera með virka átröskun við beinpéttnimælingu og hafa greinst með lystarstol í veikindaferlinu. Einnig var lystarstolshópurinn talsvert yngri en samanburðarhópurinn, allt niður í 18 ára, og hugsanlega voru ekki allar konurnar búnar að ná hámarksbeinpéttni sinni í lendhrygg pó henni sé náð í mjöðm við pann aldur. Rannsóknarhópurinn var ungur og sá munur sem var á hópunum með tilliti til beinbrota gæti hafa reynst tölfræðilega marktækur ef yngri samanburðarhópur hefði staðið til boða. Takmarkaðar upplýsingar um brot fengust úr spurningalista við beinpéttnimælingu og vitum við pví ekki hvort um var að ræða háorku- eða lágorkubrot, en pað hefði líka verið fróðlegt að skoða. Einnig var stærð rannsóknarhóps frekar lítil og pví erfiðara að fá tölfræðilega marktækar niðurstöður. Раð er bein afleiðing af pví hve lystarstol er sjaldgæfur sjúkdómur, og er reyndar einnig vandamál í öðrum rannsóknum af svipuðum toga.

Engin viðurkennd eða áhrifarík lyfjameðferð er til sem verndar eða bætir beinpéttni hjá pessum sjúklingahópi. Ennpá hafa tilraunir með að gefa bisfosfonöt, estrógen, testósterón eða vaxtarhormón, IGF 1, borið takmarkaðan árangur. ${ }^{28}$ Pó benda nýlegar rannsóknir til að bisfosfonöt geti aukið beinpéttni í hrygg hjá fullorðnum lystarstolssjúklingum og aukið beinpéttni í lærleggshálsi hjá unglingsstúlkum með lystarstol. ${ }^{29,30}$ Lyfin eru ekki skráð hér á landi með pessa ábendingu og ætti að nota pau með mikilli varúð hjá pessum unga sjúklingahópi par til sterkari vísbendingar eru um gagnsemi peirra. Pá hefur nýlega verið sýnt fram á að með estrógenplástri eða smáum estrógenskömmtum um munn jókst beinpéttni á 18 mánaða tímabili í lendhrygg og mjöðm hjá unglingsstúlkum með lystarstol um 2,3\% og 1,1\%. ${ }^{31}$

Mikilvægasta meðferðin til að auka beinpéttni hjá sjúklingum með lystarstol er að hjálpa peim að ná kjörpyngd og koma líkamsstarfsemi í eðlilegt horf. Samhliða næringarmeðferð parf að huga að sálfræðimeðferð og annarri geðmeðferð eftir pví sem við á. Hjá pessum ungu einstaklingum er hætt við að hámarksbeinmassi verði að öðrum kosti mun lægri en ella.

\section{Lokaord}

Beinpynning er algeng hjá lystarstolssjúklingum og virðist líkamspyngd peirra vera sá páttur sem hefur mest áhrif par á. Reyndar virðast tengsl beinpéttni og líkamspyngdar vera nokkuð samfelldur ferill sem bendir til að ungar konur undir kjörpyngd séu í hættu á að ná lægri hámarksbeinmassa og próa beinpynningu frekar en kynsystur peirra sem eru í eðlilegum holdum.

\section{Pakkir}

Pakkir fær Helga Magnúsdóttir geislafræðingur fyrir aðstoð við að afla gagna. 


\section{Heimildir}

1. Grinspoon S, Thomas E, Pitts S, Gross E, Mickley D, Miller $\mathrm{K}$, et al. Prevalence and predictive factors for regional osteopenia in women with anorexia nervosa. Ann Intern Med 2000; 133: 790-4

2. Miller KK, Grinspoon SK, Ciampa J, Hier J, Herzog D, Klibanski A. Medical findings in outpatients with anorexia nervosa. Arch Intern Med 2005; 165: 561-6.

3. Milos G, Spindler A, Schnyder U, Fairburn CG. Instability of eating disorder diagnoses: prospective study. $\mathrm{Br}$ Psychiatry 2005; 187: 573-8.

4. Helverskov JL, Clausen L, Mors O, Frydenberg M, Thomsen $\mathrm{PH}$, Rokkedal K. Trans-diagnostic outcome of eating disorders: A 30-month follow-up study of 629 patients. Eur Eat Disord Rev 2010; 18: 453-63.

5. Sigurðardóttir A, Pálsson SP, Porsteinsdóttir G. Lystarstol 1983-2008 - innlagnir, sjúkdómsmynd og lifun. Leknablaðið 2010; 96: 747-53.

6. Fichter MM, Quadflieg N, Hedlund S. Twelve-year course and outcome predictors of anorexia nervosa. Int J Eat Disord 2006; 39: 87-100.

7. Theintz G, Buchs B, Rizzoli R, Slosman D, Clavien $\mathrm{H}$, Sizonenko PC, et al. Longitudinal monitoring of bone mass accumulation in healthy adolescents: evidence for a marked reduction after 16 years of age at the levels of lumbar spine and femoral neck in female subjects. J Clin Endocrinol Metab 1992; 75: 1060-5.

8. Lin YC, Lyle RM, Weaver CM, McCabe LD, McCabe GP Johnston CC, et al. Peak spine and femoral neck bone mass in young women. Bone 2003; 32: 546-53.

9. Sigurðsson G, Valdimarsson Ö, Kristinsson JÖ, Stefánsson S, Valdimarsson S, Knútsdóttir $\mathrm{HB}$, et al. Hámarksbeinmagn íslenskra kvenna. Læknablaðið 1998; 84: 96-105.

10. Assessment of fracture risk and its application to screening for postmenopausal osteoporosis. Report of WHO Study Group. World Health Organ Tech Rep Ser 1994; 843:1-129.

11. Cummings SR, Black DM, Nevitt MC, Browner W Cauley J, Ensrud $\mathrm{K}$, et al. Bone density at various sites for prediction of hip fractures. The Study of Osteoporotic Fractures Research Group. Lancet 1993; 341: 72-5.
12. Prevention and management of osteoporosis. World Health Organ Tech Rep Ser 2003; 921:1-164.

13. Olmos JM, Valero C, del Barrio AG, Amado JA, Hernandez $\mathrm{JL}$, Menendez-Arango J, et al. Time course of bone loss in patients with anorexia nervosa. Int J Eat Disord 2010; 43 $537-42$.

14. Winston AP, Alwazeer $A E$, Bankart MJ. Screening for osteoporosis in anorexia nervosa: prevalence and predictors of reduced bone mineral density. Int J Eat Disord 2008; 41: 284-7.

15. Miller KK, Lee EE, Lawson EA, Misra M, Minihan J, Grinspoon SK, et al. Determinants of skeletal loss and recovery in anorexia nervosa. J Clin Endocrinol Metab 2006; 91: 2931-7.

16. Misra M, Klibanski A. Bone health in anorexia nervosa. Curr Opin Endocrinol Diabetes Obes 2011; 18: 376-82.

17. Hartman D, Crisp A, Rooney B, Rackow C, Atkinson R, Patel S. Bone density of women who have recovered from anorexia nervosa. Int J Eat Disord 2000; 28: 107-12.

18. Hotta M, Shibasaki T, Sato K, Demura H. The importance of body weight history in the occurrence and recovery of osteoporosis in patients with anorexia nervosa: evaluation by dual X-ray absorptiometry and bone metabolic markers. Eur J Endocrinol 1998; 139:276-83.

19. Treatment of patients with eating disorders, third edition. American Psychiatric Association. Am J Psychiatry 2006 163(7 Suppl): 4-54

20. The ICD-10 classification of mental and behavioural disorders: diagnostic criteria for research. World Health Organization, Genf 1993.

21. Gudmundsdottir SL, Indridason OS, Franzson L Sigurdsson G. Age-related decline in bone mass measured by dual-energy $\mathrm{X}$-ray absorptiometry and quantitative ultrasound in a population-based sample of both sexes: identification of useful ultrasound thresholds for osteoporosis screening. J Clin Densitom 2005; 8: 80-6.

22. Sigurðsson G, Óskarsdóttir D. Mismikil beinpynning 1 lendhrygg og lærleggshálsi. Læknablaðið 1996; 82: 621-6.
23. Hofman M, Landewe-Cleuren S, Wojciechowski F, Kruseman AN. Prevalence and clinical determinants of low bone mineral density in anorexia nervosa. Eur J Intern Med 2009; 20: 80-4

24. Soyka LA, Misra M, Frenchman A, Miller KK, Grinspoon $\mathrm{S}$, Schoenfeld DA, et al. Abnormal bone mineral accrual in adolescent girls with anorexia nervosa. J Clin Endocrinol Metab 2002; 87: 4177-85.

25. Waugh EJ, Woodside DB, Beaton DE, Cote P, Hawker GA. Effects of exercise on bone mass in young women with anorexia nervosa. Med Sci Sports Exerc 2011; 43: 755-63.

26. Soyka LA, Grinspoon S, Levitsky LL, Herzog DB, Klibanski A. The effects of anorexia nervosa on bone metabolism in female adolescents. J Clin Endocrinol Metab 1999; 84: 4489-96.

27. Wong S, Au B, Lau E, Lee Y, Sham A, Lee S. Osteoporosis in Chinese patients with anorexia nervosa. Int J Eat Disord 2004; 36: 104-8.

28. Vescovi JD, Jamal SA, De Souza MJ. Strategies to reverse bone loss in women with functional hypothalamic amenorrhea: a systematic review of the literature. Osteoporos Int 2008; 19: 465-78.

29. Miller KK, Meenaghan E, Lawson EA, Misra M, Gleysteen $\mathrm{S}$, Schoenfeld D, et al. Effects of risedronate and low-dose transdermal testosterone on bone mineral density in women with anorexia nervosa: a randomized, placebocontrolled study. J Clin Endocrinol Metab 2011; 96: 2081-8.

30. Golden NH, Iglesias EA, Jacobson MS, Carey D, Meyer $\mathrm{W}$, Schebendach J, et al. Alendronate for the treatment of osteopenia in anorexia nervosa: a randomized, doubleblind, placebo-controlled trial. J Clin Endocrinol Metab 2005; 90: 3179-85.

31. Misra M, Katzman D, Miller KK, Mendes N, Snelgrove $\mathrm{D}$, Russell $\mathrm{M}$, et al. Physiologic estrogen replacement increases bone density in adolescent girls with anorexia nervosa. J Bone Miner Res 2011; 26: 2430-8.

32. Legroux-Gerot I, Vignau J, Collier F, Cortet B. Factors influencing changes in bone mineral density in patients with anorexia nervosa-related osteoporosis: the effect of hormone replacement therapy. Calcif Tissue Int 2008; 83: $315-23$

\section{ENGLISH SUMMARY}

\section{Bone mineral density of young women with history of anorexia nervosa}

Runarsdottir RG, Thorsteinsdottir G, Indridason OS, Sigurdsson G

Objective: A decrease in bone mineral density (BMD) is frequently seen in patients with anorexia nervosa (AN). This study was designed to assess BMD of young Icelandic women with current or previous history of $\mathrm{AN}$ and identify predictors which might be targets for preventive measures.

Material and methods: The study was retrospective. Participants were women aged 18-40 years, with diagnosis of AN (F50.0, F50.1) attending the anorexia unit at Landspítali - The National University Hospital of Iceland - in 2001-2009, who had undergone measurement of BMD by dualenergy X-ray absorptiometry. A control group consisted of 58 healthy 30 years old women participating in a study of bone health in 2001-2003. Results: At time of BMD measurement the median body mass index (BMI: $\left.\mathrm{kg} / \mathrm{m}^{2}\right)$ in the AN group $(\mathrm{n}=40)$ was 17.4 (12.3-25.2) compared to $23.6(18.1-43.7)$ in the control group $(p<0,001)$. Lumbar spine and hip BMD were 15.3-17.5\% lower in AN patients than in control subjects $(p<0.001)$. In both groups there was a strong correlation between BMD and body weight $(r=0.354-0.604, p<0.05)$ and lean mass $(r=0.425-0.588$, $\mathrm{p}<0.05$ ). Among patients with $\mathrm{AN}$ a correlation was also seen between $B M D$ and lowest weight during the illness $(r=0.482-0.499, p<0.01)$. Among the 26 AN patients who had repeated BMD measurement, a significant decrease in BMD at femoral neck $(-6.6 \%, p=0.030)$ was observed in those who lost weight between the measurements $(n=9)$. Those who had BMI $\leq 17.5$ between BMD measurements lost $5.5-7.1 \%$ of the BMD at the hip $(\mathrm{p}<0.05)$.

Conclusion: Young women with AN have $15 \%$ lower bone mass than healthy young women. The relationship between BMD and body weight seems to be a continuum across disease states. Increased body weight may be the most important factor for recovery of bone mass in AN patients.

Key words: bone mineral density, anorexia nervosa, peak bone mass, body weight.

Correspondence: Gunnar Sigurðsson, gunnars@landspitali.is

${ }^{1}$ Faculty of Medicine, University of Iceland, ${ }^{2}$ Department of Psychiatry, Eating Disorder Unit, Landspitali - The National University Hospital of Iceland, ${ }^{3}$ Department of Nephrology, Landspitali, ${ }^{4}$ Department of Endocrinology, Landspitali. 